\title{
Evgenij Jablokov*
}

ROSYJSKA AKADEMIA NAUK - INSTYTUT SŁOWIANOZNAWSTWA MOSKWA

ORCID: 0000-0002-7926-1689

\section{Мировое трезвучие. Рассказ Андрея Платонова «Фро»:}

\section{символика сюокета}

\section{и смысл заглавия}

«Фро» (1936 г.) принадлежит к числу известнейших произведений Платонова и представляет собой яркий примерхарактерногодляего творчества I930-X - I940-х гг. жанра «философской мелодрамы». Многими читателями (да и некоторыми литературоведами) рассказ воспринимается как сентиментальная семейная зарисовка; однако по содержанию он далеко выходит за рамки бытового психологизма. Главные герои, воплощающие, как кажется, традиционную оппозицию мужского и женского психотипов, вместе с тем представлены как взаимодополняющие элементы всеединства, символом которого выступает «заглавный» оним рассказа.

Традиция сугубо «жизнеподобного» толкования «Фро» сложилась ещё в 1930-х - 1940-х гг.; критики усматривали в рассказе конфликт глобально-преоб-

\footnotetext{
* Prof. Evgenij Aleksandrovich Jablokov - filolog-literaturoznawca, profesor nauk humanistycznych. Autor wielu książek, poświęconych m.in. twórczości Michaiła Bułhakowa, Andrieja Płatonowa i Aleksandra Grina: «Ha берегу неба: роман Андрея Платонова “Чевенгур”» (200I), «Художественный мир Михаила Булгакова» (200I), «Нерегулируемые перекрестки: о Платонове, Булгакове и многих других» (2005), «Роман Александра Грина “Блистающий мир”» (2005), «Михаил Булгаков и мировая культура: справочник-тезаурус» (2011), «А.С. Грин в жизни и творчестве» (2012), «Путеводитель по роману А.П. Платонова “Чевенгур”» (2ог 2), «Хор солистов: проблемы и герои русской литературы первой половины ХХ века» (2ог4), «Подвал мастера. М.А. Булгаков: поэтика и культурный контекст» (20I8), «Исцеляющий миф: коды традиционной культуры во “врачебных” рассказах М.А. Булгакова» (2019), «Москва Булгакова» (2020) «Тараканий век. Энтомоморфные персонажи Михаила Булгакова в русле литературной традиции» (2020), «Дети и взрослые в мире Андрея Платонова» (2021).
} 
разовательной и локально-семейной установок (выражаясь в духе героя Ф. Ницше - оппозицию «дальнего» и «ближнего» $\left.{ }^{1}\right)$. Сюжет в целом даёт основания для подобной интерпретации: Фёдор не может вести «домашнее» существование, поскольку увлечён идеей всемирной «гармонизации», ради которой готов фактически отказаться от молодой жены - подобной акцией героя (либо попыткой её совершить) оканчивается рассказ. Именно такую коллизию подчёркивали современные Платонову критики, делая при этом неутешительный (по идеологическим критериям эпохи) вывод, что автор «Фро» сочувствует «консервативной» героине куда больше, чем «прогрессивному» герою, и личное в рассказе торжествует над общественным. Характерен пассаж из статьи (1937 г.) А.С. Гурвича:

Строки, описывающие любовь Фёдора и Фро, нельзя читать без чувства неловкости. Возлюбленные отгородились от мира, бросили свои дела, забыли трудовые обязанности, заглушили свои гражданские чувства ${ }^{2}$.

Сопоставляя «Фро» с платоновскими рассказом «Такыр» (1934 г.) и статьёй «Пушкин - наш товарищ» (1937 г.), критик заявлял, что тоскующая о муже, но надеющаяся на встречу с ним героиня воплощает торжество мещански-семейного, «природного» начала:

Ей принадлежит последнее слово в рассказе. <... ...Как бы стремительно ни бежал Федор, всё равно надменная лукавая улыбка Фро его настигнет, и он вернется. <...> Победит тихая песня мелкой, ничтожной птички, сколько бы ни душила её общественная трудовая жизнь ${ }^{3}$.

Устойчивость такой интерпретации подтверждают внутренние рецензии на планировавшийся к изданию посмертный сборник произведений Платонова. Один из рецензентов, А.А. Бек I6 марта 1952 г. писал о «Фро»: «<...> автор как бы утверждает, что революция, общественные интересы, долг губят, подавляют любовь. Такая идея рассказа делает талантливый рассказ реакционным» ${ }^{4}$. В подобном духе высказывался ІІ января 1952 г. и А.Б. Чаковский: «<...> одно из двух: или любовь, или труд. <...> Фро уверена в том, что Фёдор скоро вернется к этой всепобеждающей любви» ${ }^{5}$. Героиня, всецело поглощённая своими

1 Нищше Ф. Так говорил Заратустра // Ницше Ф. Сочинения. В 2 т. Москва: Мысль, 199о. Т. 2. C. 43 .

2 Гурвич A.С. Андрей Платонов // Андрей Платонов: Воспоминания современников. Материалы к биографии. Москва: Современный писатель, 1994. С. 398.

3 Там же. С. 399-40о.

4 Первые посмертные сборники А. Платонова: отзывы современников // «Страна философов» Андрея Платонова: проблемы творчества. Москва: ИМЛИ РАН, 2о17. Вып. 8. С. 578.

5 Там же. С. 574. 
чувствами, вызывала явную антипатию - показательно мнение (2 января 1953 г.) П.Н. Омилянчука:

В рассказе проповедывается, по существу, патологический романтизм, не оправданный никакой психологией. У Фро какая-то животная и не человеческая любовь. Что стоит описание того времени, когда Фро находилась с мужем после разлуки <...> Чтение этих страниц вызывает отвращение

И.А. Арамилев заявлял (го июля І95і г.): «Героиня рассказа <...> существо изломанное, с декадентскими причудами, с юродством. <...> Может быть, лучше снять (изъять из сборника. - E. Я.) эту порочную вещь» ${ }^{7}$. Ему вторил (зо июля I952 г.) М.Р. Шкерин: «Рассказ пошл от начала до конца» ${ }^{8}$.

M.M. Скуратов (І7 сентября 1952 г.) в связи с «Фро» сосредоточил особое внимание на языке Платонова, чьи «литературные выкрутасы» ${ }^{9}$, по мнению рецензента, в данном случае достигли апогея:

Желание выкинуть тот или иной словесный фортель, сказать не как все, а особенно замысловато, - в этом рассказе переходит все границы <...> Непредубеждённый читатель при чтении подобных рассказов может воскликнуть: - Чушь! Тарабарщина! Не русский язык! ${ }^{10}$

Под «непредубеждённым читателем», видимо, подразумевался И.В. Сталин, который двадцатью годами раньше, прочитав платоновскую повесть «Впрок», среди энергичных заметок на полях опубликовавшего её журнала «Красная новь» (193г. № 3) оставил, в частности, такую: «Это не русский, а какой-то тарабарский язык!» ${ }^{11}$

Вряд ли можно утверждать, что «Фро» сугубой стилистической «аномальностью» отличается от общего фона платоновских художественных текстов І930-х гг. Название рассказа тоже вполне соответствует ряду «имённых» заглавий в других произведениях писателя - «Семён» (1936 г.), «Алтеркэ» (1939 г.), «Уля» (1939 г.), «Никита» (1945 г.), каждое из которых сигнализирует о важности ономастического дискурса. Впрочем, по сравнению с ними «Фро» имеет существенное отличие: здесь, как и в написанном по мотивам рассказа киносценарии «Воодушевление» (1936 г.), героиня наделена двойным именем. В сюжетном плане это может трактоваться как знак «нецельности», тенденции к «самоостранению». Но в общей системе произведения номинационная коллизия не

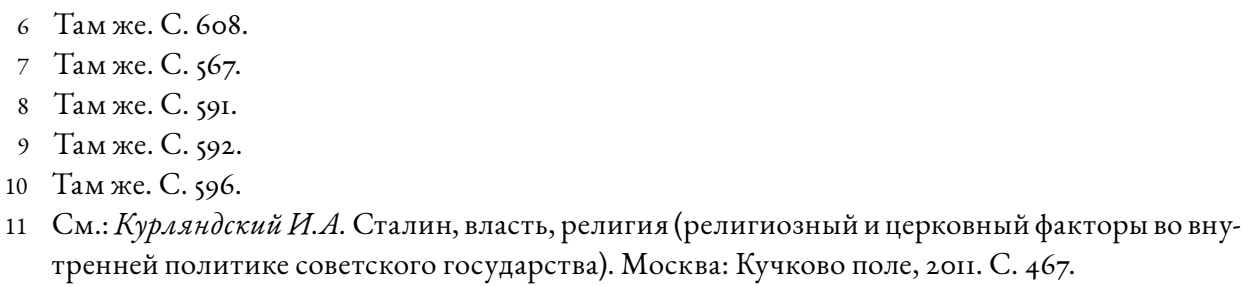


исчерпывается личностно-психологическими аспектами и является показателем бытийно-философских проблем; именования, хотя и относятся к одному и тому же персонажу, нетождественны друг другу по сущностному содержанию.

Заглавие в рассказе выступает исходным пунктом ономастической игры и кажется «немотивированным», если обратить внимание на явную статистическую диспропорцию. В тексте под названием «Фро» этот экзотический оним фигурирует 23 раза (в нарративе самой героини, Фёдора и, в единичных случаях, повествователя), в то время как узуальный диминутив «Фрося» употреблён Із І раз - так называют героиню другие персонажи (за исключением мужа) и, в подавляющем большинстве случаев, повествователь. Кроме того, в «официальных» ситуациях два раза упомянута полная форма её имени с фамилией: Ефросинья Евстафьева [4: 409, 4I3 $\left.{ }^{12}\right]$. В связи с коллизией «раздвоенности» немаловажно, что в рассказе также имеется не произносящая ни слова тёзка героини, дважды названная Фросей [4: 409-4Іо] и один раз - Ефросиньей; фамилия остаётся неизвестной, поскольку её владелица по неграмотности ставит вместо подписи «три буквы, похожие на слово “Ева”, с серпом и молотом на конце» [4: 410]. Соответственно, каждая из тёзок-двойников имеет по три онима: одна - Ефросинья (Евстафьева) / Фрося / Фро; другая - Ефросинья / Фрося / «Ева» (последний оним либо инициалы имени и фамилии, либо часть фамилии вроде «Евстафьева»).

В сценарии «Воодушевление» ${ }^{13}$ героине дана пара имён Арфа / Марфа. Повествователь постоянно именует её Арфой, такой же оним два раза употребляет Фёдор [7: 507, 520], кроме того, подруга героини Лида в одном из эпизодов обращается к ней «Арфочка» [7: 494]. Узуальное имя фигурирует в тексте (помимо афиши [7: 477]) лишь дважды, причём исключительно в виде диминутивов «Марфуша» и «Марфушка» [7: 499, 509], которые использует отец героини.

Приведённые наблюдения заставляют прежде всего задуматься о соотношении онимов «Фрося» и «Фро». Последний возникает (не считая заглавия) почти в середине рассказа - в сцене танца с диспетчером героиня называет себя «Фро» [4: 4II-4I2], и это имя звучит в повествовании, ориентированном на точку зрения партнёра [4: 4I2]. В следующем әпизоде обращение «Фро» появляется в телеграмме Фёдора [4: 4I2] - логично предположить, что оно «семейное», его «авторство» принадлежит Фёдору и героиня, именуя себя таким образом, «цитировала» мужа. Затем оним возникает, когда она бесцельно бродит вокруг станции, томясь воспоминаниями о Фёдоре: «“Ах, Фро, Фро, хоть бы обнял тебя кто-нибудь!” - сказала она себе» [4: 4I7]; формально речь идет об «адюльтере» ${ }^{14}$,

12 Тексты Платонова, кроме специально отмеченных случаев, цитируются по: Платонов А.П. Собрание. В 8 т. Москва: Время, 2оІІ-2ог2, с указанием тома и страницы.

13 При анализе мы будем уделять преимущественное внимание рассказу «Фро», а сюжетно близкий (но не вполне тождественный) ему сценарий привлекать для сравнения.

14 Подчеркнём фонетическое сходство слов «станция» и «танец», тем более что контакт с диспетчером во время танца представлен как акт «суррогатной» близости с мужем: «Фро <...> прилегла к его груди, к его галстуку, и галстук сдвинулся под тяжестью её головы в сторону, а в сорочке образовалась ширинка с голым телом. <...> Он почувствовал, что по его груди, 
однако ситуация обусловлена отсутствием мужа. Далее имя «Фро» произносит он сам, когда, приехав по телеграмме, видит героиню на станции [4: 42I]. Затем оним несколько раз употребляется в описаниях их общения [4: 422-423] вперемешку с именем «Фрося», но и здесь заметна тенденция связывать оним «Фро» с точкой зрения Фёдора. В финале этот оним дважды звучит в сцене «заочного» расставания с мужем, когда отец сообщает дочери, что Фёдор уехал практически навсегда («Как, говорит, поделает все дела, так либо сюда вернётся, либо тебя к себе выпишет» [4: 424]), но героиня предвидит новую встречу («Прощай, Фёдор! Ты вернёшься ко мне, и я тебя дождусь!» [4: 425]). Показательно, однако, что именованием «Фро» повествование не заканчивается - в последнем абзаце, описывающем встречу с мальчиком, героиня названа Фросей [4: 425].

Наблюдения позволяют не только сделать вывод, что оним «Фро» связан с обоими главными героями, но также - с учётом фонетической близости имён «Фрося» и «Фёдор»- предположить, что он служит «диминутивом» дяя них обоих (при этом в имени «Фрося» звуковой комплекс «Фро» присутствует непосредственно, а в имени «Фёдор» - в инвертированном виде). «Двойной» характер онима подкреплён мотивом «неразрывности» героев. Объявленный «почти безвозвратным» [4: 402] первый отъезд Фёдора обернулся его скорым возвращением к Фро; сходным образом второе («нечувствительное» для спавшей героини, как бы онирическое) исчезновение мужа фактически сразу переходит в новую - символическую - встречу с ним в «малолетнем» виде. Давно отмечено, что безымянный мальчик предстаёт двойником Федора на детской фотографии ${ }^{15}$, - сходство между этими персонажами очевидно: «мальчик с большой младенческой головой <...> и босой» [4: 405] / «босой мальчик с большой, детской головой» [4:424].

Впрочем, на снимке видны не только маленький Фёдор, но и наивно изображённая на заднике «прекрасная жизнь», по поводу которой далее сказано: «Прекрасная жизнь была в самом этом мальчике» [4: 405]. Фразу можно понять в двух (не обязательно взаимоисключающих) смыслах: либо ребёнок сам по себе гармоничен и «самодостаточен», либо в нём ощущается столь мощная преобразующая энергия, что он потенциально способен воплотить иллюзию в реальность. Суть рассказа именно в том, что два этих образа бытия - «наличная» гармония настоящего и «творимая» гармония будущего - персонифицированы в двух главных героях и не противоречат друг другу, а представляют взаимодополняющие типы отношений человека с бытиём. Подчеркнём неоднократно высказывавшийся нами тезис о том, что платоновская картина мира изначально амбивалентна, в ней сочетаются активно-преобразующая и пассивно-идеализирующая интенции ${ }^{16}$. Уже в раннем творчестве писателя налицо, с одной стороны,

оголившейся под галстуком, пробираются щекочущие капли влаги - там, где растут у него мужественные волосы» [4: 412].

15 См.: Жолковский А.К. «Фро»: пять прочтений // Вопросы литературы. 1989. № I2. С. 30.

16 См.: Яблоков Е.A. Платонов и литература // Wiener Slawistischer Almanach. 2009. Bd. 63. S. $254-256$. 
«всемирно-революционный» императив покорения и пересоздания природы, с другой - сентиментальный пафос непостижимости вселенской гармонии; одновременно декларируются необходимость мужественно-беспощадной борьбы во имя «завершения» мира и детски-послушное «подчинение» ему, возвращение к утраченной идиллии, растворение в «материнской» космической нирване. Әти взаимно противоположные установки ассоциируются с героями рассказа. Если с Фёдором связана модель безграничного расширения, «собирания» пространства ${ }^{17}$, то для Фроси характерны «точечное» состояние (пребывание в границах городка, «странствия» вокруг станции, кружение в танце) и связь с «вертикальной» координатой (работа в шлаковой яме, созерцание солнца и звезд, доносящаяся сверху музыка, приглашение мальчика, играющего внизу, во дворе). Фигурально говоря, Фрося не может покинуть «своё» место - недаром, например, ни у кого в рассказе не возникает идея, чтобы жена поехала вместе с мужем, хотя по-житейски это было бы логично.

В конкретно-историческом плане Фёдор предстаёт «культурным героем», воплощая революционно-«прогрессивную» установку. При этом весьма существенно, что он лишён «сверхчеловеческих» качеств. В характере персонажа, который «чувствует машинные механизмы с точностью собственной плоти» [4: 4I3], доминирует не «железный» пафос покорения природы, а способность к универсальной эмпатии и «оживлению» неорганического вещества:

Он одушевлял всё, чего касались его руки или мысль, и поэтому приобретал истинное представление о течении сил в любом механическом устройстве и непосредственно ощущал страдальческое, терпеливое сопротивление машинного телесного металла. <... ...Катушки, мостики Уитстона, контакторы, единицы светосилы стали для Фроси священными вещами, словно они сами были одухотворенными частями её любимого человека <... ...Фёдор сам преврашался на время в микрофараду и в блуждающий ток. Фрося почти видела глазами то, что раньше лишь хотела и не могла понять. Это были такие же простые, природные и влекушие предметы, как разночветная трава в поле [4: 413-4I4].

Пребывая в родственной слиянности с бытиём, Фёдор подобен безымянному мальчику, чей инструмент - «губная гармония» [4: 4I3], претворяющая дыхание

$17 \mathrm{C}$ «горизонтальным» движением связан и отец Фроси - Евстафьев, фамилию которого дочь продолжает носить и в браке, как бы не полностью перейдя в сферу мужа (фамилия Фёдора нам вообще неизвестна). Но, в отличие от зятя, стремящегося «неопределённо» далеко, паровозный машинист, естественно, движется по заданной линии и по ней же должен возвращаться к исходной точке; персонажи символизируют оппозицию двух типов движения - «центробежного» («расширяющего» пространство, подобно странничеству) и возвратно-поступательного. Характерно, что они наделены каламбурно «антонимичными» именами Фёдор / Нефёд (буквально «не-Фёдор»). 
в музыку, - своей «воздушностью» ассоциируется с «душой мира» ${ }^{19}$. Музыка ребёнка «бесплотна», в частности, оттого, что у малолетнего персонажа закономерно отсутствует «әротически-телесное», а говоря шире - дифференцирующее, форморазличительное восприятие реальности: «Музыкант был ещё мал, он ещё не выбрал изо всего мира что-нибудь единственное для вечной любви, его сердие билось пустым и свободным, ничего не похищая для одного себя из добра жизни» [4: 416]. По-детски «целостное» отношение к бытию сохранилось и в мироощущении Фёдора. Однако смысл его нынешней, «взрослой» деятельности в том, чтобы исконное родство с мировой сущностью «овеществилось» в материальной форме, путём соединения разрозненных объектов и явлений, - Фёдор намерен «посредством механизмов преобразовать весь мир для блага и наслаждения человечества» [4: 403]. Реализовано основополагающее для платоновской концепции представление о революционном развитии как движении вперёд ради возвращения универсума к «детскому» состоянию и воссоздания исконного «райского» бытия. Не случайно, обретая в «маленьком госте» [4: 425] мужа с детской фотографии, героиня испытывает ощущение всеединства - «узнаёт» в мальчике «человечество, о котором Фёдор говорил ей милые слова» [4: 425].

Звучащий «по-детски» оним «Фро» напоминает существительное среднего рода. В сцене финального свидания героини с «мужем-мальчиком», разумеется, нет эротических и вообще гендерных элементов - они подразумеваются лишь в «снятом» виде. Налицо андрогинические ассоциации, которые по-своему сочетаются с темой музыки. В диалоге Платона «Пир» рассказано, что непосредственное участие в разделении андрогинов «по полам» принимал Аполлон ${ }^{20}$. В рассказе Платонова представлен, по сути, «обратный» сюжет, завершающийся «бесплотным» слиянием мужского и женского начал в образе чужого ребёнка, - мальчик-музыкант, в чьём образе травестированы аполлинические черты, «восстанавливает» единство героев. Существенно, что полное имя платоновской героини, Ефросинья, намекает на «родство» с одной из харит ${ }^{21}$. В мифологической традиции хариты (грации), богини красоты, изящества и вечной юности, считались спутницами Афродиты ${ }^{22}$, но вместе с тем были связаны с Аполлоном ${ }^{23}$ - характерно предание о делосской статуе Аполлона, державшего

19 «Душа мира» (1920 г.) - ранняя статья Платонова, заглавие которой демонстрирует знакомство с идеями Платона (см.: Платон. Тимей // Платон. Собрание сочинений. В 4 т. Москва: Мысль, І994. Т. 3. С 437) и В.С. Соловьева: «Мировая Душа - единая внутренняя природа мира, мыслимая как живое существо, обладающее стремлениями, представлениями и чувствами» (Соловьев В.С. Статьи из Әнциклопедического словаря // Соловьев В.С. Собрание сочинений. В го т. 2-е изд. Санкт-Петербург: Просвещение, І9І4. Т. Іо. С. 246).

20 Платон. Пир // Платон. Собрание сочинений. В 4 т. Москва: Мысль, 1993. Т. 2. С. 99-Іоо.

21 См.: Жолковский А.К. «Фро»: пять прочтений. С. 39.

22 См.: Гомер. Одиссея / пер. В.А. Жуковского. Москва, Ленинград: Academia, I935. С. I7I, 344.

23 См.: Пиндар. Олимпийские песни // Пиндар. Вакхилид. Оды. Фрагменты. Москва: Наука, I980. C. 56-57. 
на ладони трех харит с лирой, флейтой и свирелью в руках ${ }^{24}$. В финале рассказа «Фро» земная «грация» с «пошлой наружностью» [4: 403] опускается на пол перед маленьким «гармонистом» [4: 425], словно перед божеством.

Следует подчеркнуть, что, изображая амбивалентное сосуществование «форм» всеединства, автор рассказа реализует омонимичные значения слова «гармония» - оно не только связано с «воздушной» музыкой, но и сочетается с таким, казалось бы, «непоэтическим» понятием, как железо. О пребывании героини «на курсах железнодорожной связи и сигнализации» говорится:

Она <...> с печалью слушала речь преподавателя о влиянии насыщения железа на появлениевысшихгармоник. <..> ...Высшихгармоник тока она не понимала нисколько: в её памяти звучала всёвремя однообразная песенка детской губной гармонии: «Мать стирает бельё, отец на работе, не скоро придет, скучно, скучно одному» [4: 4I4].

Не в силах постичь «железные» гармоники (кстати, оним «Фро» созвучен sam. ferrum - «железо»), героиня думает о губной гармонии. Однако этот музыкальный инструмент в реальности выглядит именно железным - его верхняя и нижняя крышки, а также голосовые планки с язычками сделаны из металла. Показательно, что если сначала звук гармонии слышится сверху, то в финальной сцене героиня из окна второго этажа видит мальчика играющим во дворе [4: 424] - музыка «спустилась» на землю. Эти символичные детали подкрепляют мысль о том, что мальчик воплощает «компромиссный» вариант гармонии, в котором материя и дух соединены как равноправные «компоненты» бытия.

Обратим также внимание на музыкальный дискурс в сценарии «Воодушевление», где, по условиям жанра, сюжетные метафоры более рельефны, отчетливы, нежели в рассказе. По сравнению с «Фро» оним «Арфа» семантически «прозрачнее» и непосредственно уподобляет героиню музыкальному инструменту. Арфа выглядит воплощённой частицей «мировой музыки» ${ }^{25}$, образ которой, представленный в книге Платона «Государство» ${ }^{26}$, в более поздней традиции

24 См.: Гаспаров М.Л. Примечания // Пиндар. Вакхилид. Оды. Фрагменты. Москва: Наука, 1980. C. 415 .

25 Сравним эпизод романа «Чевенгур» (1927 г.), где, отвечая Лую, спросившему, «на кого похож человек», Прокофий Дванов говорит: «На открытый океан, дорогой товарищ, и на гармонию схем!» [3: 215]. Каламбурно перефразированное понятие «гармония сфер» при этом дополнительно «остраняется»: «Луй не видел, кроме рек и озёр, другой воды, гармонии жезнал только двухрядки» [3: 215]. Вследствие смысловой игры человек оказывается сопоставлен с гармонией / гармонью - сходным образом в сценарии «Воодушевление» героиня являет собой буквально «живую арфу».

26 См.: Платон. Государство // Платон. Собрание сочинений. В 4 т. Москва: Мысль, 1994. Т. 3. C. 416 . 
был соотнесён с музыкой земной ${ }^{27}$ и сближен со звучанием лиры или кифары - характерно, что героиня «Воодушевления» получает имя сходного музыкального инструмента. При этом она вполне успешно общается с «железным» миром - например, вручную качает смазку на паровозе [7: 520-52I], благодаря чему Фёдору удаётся успешно провести сверхтяжёлый состав.

В сценарии нет обучения Арфы на курсах, но образ гармонии «раздвоен» не менее наглядно: присутствуют два одноимённых, но при этом разных музыкальных инструмента и два мальчика. Губной гармонике играющего в верхней квартире ребёнка «лет 5-6» [7: 477] противопоставлена гармонь в будке путевого обходчика, выступающая как бы символом «земной» суеты. Это атрибут родителей «мальчика лет 8-Іо» [7: 477], постоянно пребывающих в состоянии «гульбы» по странным поводам - «кума в колхозе померла» [7: 485], «дядя с раскулачки вернулся» [7: 5Іо]; характерно и то, как реагирует на подобное времяпровождение сын: «Пускай гуляют, всё равно скоро помрут...» [7: 510]. Вместо них мальчик сам выполняет функции обходчика; на фразу Евстафьева: «Гляди тут за поездами, а то, знаешь, опасно», - он отвечает: «Ничего: я погляжу за ними» [7: 485]; в отличие от ребёнка с «воздушной» гармонией, от этого мальчика зависит порядок на «земле». Характерно, что, когда Иных дарит ему свои часы - символ будущего, у мальчика проявляется «педагогическая» интенция: «Пойду отца с матерью ругать» [7: 5іо].

По сравнению с «Фро», в «Воодушевлении» значительно больше эпизодов с мелодией губной гармонии: в рассказе их три [4: 4I3, 4I6, 424], а в сценарии - восемь [7: 491, 499, 502, 511, 513-514, 523-524], этот звук служит лейтмотивом действия ${ }^{28}$. Показательно, однако, что в финале сценария ребёнок-музыкант не встречается с героиней. Арфа из окна зовёт его в гости, но в этот момент является посыльный из депо, куда Арфу вызывают, чтобы чествовать их с Фёдором. Та уходит, и в это время появляется (непонятно как разминувшийся с ней) мальчик. Он прогоняет воробья, клюющего на столе торт, и ест его сам, после чего кладёт губную гармонию в коробку с остатками торта и уносит их с собой, забирая также «мыло с картинкой» и «красивый пузырёк с духами» [7: 524]; затем со двора вновь доносятся звуки гармонии - этим завершается действие.

27 См.: Никомах Геразский. Руководство по гармонике // $\Sigma$ ХО АН. 20о8. Т. 2. № I. С. 77-78; Боэиий A.M.C. Основы музыки. Москва: Московская консерватория, 2012. С. 57, 59.

28 В отличие от рассказа, в сценарии «просьба» Арфы к невидимому мальчику, чтобы он играл, звучит не один раз [4: 416], а трижды [7: 49I, 502, 523]. К тому же здесь звук губной гармонии «взаимодействует» не только с героиней. В одном из эпизодов мелодия звучит над вернувшимся из ссылки и заснувшим Фёдором [7: 5II], в другом - Евстафьев (раздражённый тем, что вести сверхтяжёлый состав поручено не ему, а Фёдору), услышав музыку, кричит наверх: «Замолчи там, стервец!» - причем фраза вызывает реакцию: «Гармоника сразу умолкает, и слышно стало, как заплакал ребенок» [7: 5I4]. Впрочем, до этого Евстафьев называет (скорее в похвальном смысле) стервецом и другого, «земного» мальчика, который на переезде махал красным флажком, пытаясь сигнализировать машинисту, что у того горит букса [7: 484]. 
Таким образом, в сценарии сюжет смещён в «производственную» сферу, Арфа и Фёдор составляют не только семью, но и паровозную бригаду. Семейное несчастье, которым открывается действие, тоже обусловлено производственной деятельностью: Фёдор несправедливо обвинён в аварии и отправлен (как бы сослан) «на дальнюю дорогу» [7: 478]; впрочем, в итоге героя возвращают домой, причём наркомпуть Каганович лично присылает ему телеграмму с извинениями [7: 498]. С железной дорогой связаны и моменты наивысшего эмоционального подъёма: при начале движения состава Фёдор показан в состоянии трудового энтузиазма - его лицо «в поту и вдохновении» [7: 517]. Сходным образом изображён Евстафьев, наблюдающий состав со стороны и имитирующий движения машиниста: «Он в слезах и в восторге» [7:484], - налицо «энергия сочувствия и воображения» [7:485]. Этим мотивировано заглавие сценария, семантически балансирующее между понятиями «душа» и «дух»: воодущевление, обретение трудового энтузиазма, читается как одухотворение; заметим, что греч.

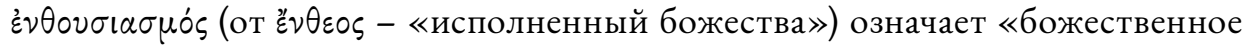
вдохновение, воодушевление, восторг».

Возвращаясь к рассказу «Фро», подчеркнём, что финальная сцена, где героиня как бы поклоняется носителю «воздушной» музыки (который, впрочем, не «нисшёл», а «поднялся» в её комнату), вызывает ассоциации с Благовещением. Коннотации «вестника» подкрепляются весьма активным в рассказе почтовым дискурсом. Приведём лишь перечень соответствующих мотивов: почтовый ящик, к которому подходит героиня в начальной сцене [4: 403], - телеграмма Фёдора [4: 4I2] - «письмо» Фроси в учебной тетради [4: 4I4] - ожидание письма или телеграммы от Фёдора и поступление героини в почтальоны [4: 4I8] - телеграмма от Фёдора [4: 419] - ответная телеграмма Фроси с алогичным текстом [4: 420] - передаваемое отцом заявление Фроси об увольнении [4: 420] - телеграмма Фёдора [4: 42I] - устное (переданное через отца) «послание» Фёдора в финале [4:424] - адресованная Фёдору и как бы переданная ему «воздушным» путём «прощальная» фраза героини о неизбежности новой встречи [4: 425].

В «почтовую» парадигму встраивается и «бой цветов» [4: 4II]. Вероятно, имеется в виду популярная игра «флирт цветов», представлявшая собой имитацию любовной переписки - «обмен карточками (письменными репликами “амурного” содержания) <...> Одна - изнаночная - сторона карточек выглядела на манер "рубашки” игральных карт, на другой стороне значились названия цветов в паре с короткими фразами» ${ }^{29}$. Кстати, эпизод «флирта цветов» ${ }^{30}$ есть в опубликованном незадолго до создания «Фро» романе Н.А. Островского «Как закалялась сталь» (1934 г.), где к тому же фигурирует восемнадцатилетняя судомойка по имени $Ф$ рося $^{31}$, угнетённое положение которой рождает в Павле

29 Борисов С. «Давайте флиртовать, товарищи!» // Родина. 2019. № 5. С. 126.

30 См.: Островский Н. Как закалялась сталь // Островский Н. Сочинения. В 3 т. Москва: Правда, 1969. Т. г. С. 274.

31 Там же. С. 26-27. 
классовую ненависть ${ }^{32}$; позже, во время гражданской войны Фрося, будучи санитаркой в госпитале, ухаживает за тяжело раненным Корчагиным ${ }^{33}$.

Своеобразной «реализацией» мотива Благовещения выглядит финальный эпизод рассказа, где героиня «присваивает» чужого ребёнка - который в аспекте евангельских коннотаций ${ }^{34}$ травестийно сочетает функции «ангела» и возвещаемого им «Сына человеческого» (напомним, что мальчик ассоциируется для Фроси с «человечеством»); словосочетание «маленький гость» ${ }^{35}[4: 424]$ звучит явно символично. При этом перспективы собственного материнства героини неопределённы даже после чуть ли не двухнедельного «неразлучного свидания» [4: 424], то есть беспрерывного секса, с Фёдором. Представляется справедливым суждение А.К. Жолковского: «<...> материнство Фро остается желанием, метафорой, жестом - в рассказе нет свидетельств о предполагаемой некоторыми критиками беременности $\Phi$ ро» ${ }^{36}$. Хотя имеется немалое число деталей, которые могут трактоваться именно как соответствующие «намёки». Так, приобщение героини к почтовой сфере, принятие функции «вестницы» (ради того, чтобы самой побыстрее получить письмо от мужа) непосредственно ассоциируется с деторождением: «На утренней заре она быстро шла по улице посёлка $c$ mяжелой сумкой на животе, как беременная, стучала в двери и подавала письма и бандероли людям в подштанниках, оголённым женщинам и небольшим детям, проснувшимся прежде взрослых» [4: 4I8]. Генеративная тема акцентирована и в других эпизодах: «<...> кто в клуб танцевать, кто домой - детей починать!» [4: 4IO]; «музыка играла фокстрот “Мой бебе”» [4: 4II]; «Фрося хотела, чтобы у нее народились дети» [4: 423].

Однако в финале «муж» является Фросе в «детском» образе - в виде чужого ребёнка; этому соответствуют присутствующие в рассказе коннотации «небеременности» ${ }^{37}$. Например, среди «бытовых вопросов», задаваемых «адресатами» ${ }^{38}$ разносящей почту героине, есть один, который воспроизведён, кажется, в единственном издании рассказа. Между тем без этого краткого диалога эпизод лишается существенных смысловых оттенков:

32 В 1937 г. Платонов написал статью «Павел Корчагин», где говорится в том числе о Фросе [8: 153-154], а в 1939 г. - книгу об Островском (её текст не найден).

33 См.: Островский Н. Как закалялась сталь. С. 184.

34 Лк. 1:26-32.

35 В сценарии «Воодушевление» евангельские мотивы пира и гостя (Лк. І4:І-24) обретают комично «наглядный» вид: воробей и мальчик-музыкант «соперничают» из-за торта.

36 Жолковский A.К. «Фро»: пять прочтений. С. 3 г.

37 Характерно, что тридиатилетняя «рабочая подруга» [4: 409] Фроси, притом носящая символичное имя Наталья (лam. natalis - «относящийся к рождению»), по-видимому, бездетна - по крайней мере, о детях не упоминает, говоря лишь о муже и «полюбовнике» [4: 409].

38 Платонов А.П. Фро // Платонов А.П. Течение времени. Москва: Московский рабочий, 1971. C. 403. 
«А во время месячных очищений вы тоже ходите или дают послабление?» «Послабление, - сообщала Фрося, - казённый пояс дают, я еще не получала его». - «Дадут, - обемал адресат, - он ведь полагается» ${ }^{39}$. Один получатель журнала «Красная новь» предложил Фросе выйти за него замуж - в виде опыта: что получится, может быть, счастье будет, а оно полезно. «Как вы на это реагируете?» - спросил подписчик. «Подумаю», - ответила Фрося. «А вы не думайте! - советовал адресат. - Вы приходите ко мне в гости, почувствуйте сначала меня: я человек нежный, читающий, культурный - вы же видите, на что я подписываюсь! Это журнал, выходит под редакцией редколлегии, там люди умные - вы видите - и там не один человек, и мы будем двое! Это же всё солидно, и увас, как узамужней женщины, авторитета будет больме!.. А девушка, это что - одинока, антиобщественница какая-то. ${ }^{40}$

Будучи сопоставлено с «месячными очищениями», название «Красная новь ${ }^{41}$ фонетически ассоциируется со словом «кровь» ${ }^{42}$, явствен сарказм по адресу ежемесячного органа ${ }^{43}$. Что касается сюжетного плана - в репликах «под-

39 Данный фрагмент отсутствовал уже в первых (1936-1937 гг.) публикациях рассказа - вероятно, был исключен (и до сего времени продолжает изыматься) стыдливыми редакторами по этическим соображениям. При этом во всех изданиях «Фро» неизменно воспроизводится «наивный» вопрос отца героини: «Что ж ты сегодня себе губки во рту не помазала? <...> Иль помада вся вышла, - так я сейчас куплю, сбегаю в аптеку...» [4: 4I5]. Сходная травестия физиологических функций имеет место в рассказе «Река Потудань» (1936 г.), где мотив «проблематичного» деторождения не менее важен, чем во «Фро»: у Любы после попытки покончить жизнь самоубийством «кровь горлом часто идёт» [4: 452]. Подобные мотивы есть и в более ранних платоновских произведениях. Так, в романе «Чевенгур» малолетний Прошка Дванов сообщает Захару Павловичу: «Я матерь больше люблю, у нее кровь из нутра льется. Я рубашку ей раз стирал, когда она хворала» [3: 48]. Из того же ряда - дневниковая запись Симона Сербинова: «Я побочный продукт своей матери, наравне с ее менструацией, - не имею поэтому возможности что-либо уважать» [3: 362]. В повести «Ямская слобода» (1927 г.) «охальный и умный мальчик» Васька рассказывает Филату: «Мать вчера чугунок со щами пролила, а отец ей как дёрнул рогачом по пузу... А мать кричит, что у ней краски тронулись, правда! Отец говорит: “Крась крышу, шлюха“, - а мать не полезла на чердак, а легла на койку и плачет! Она всегда у нас притворяется!..» [2: 271].

40 Платонов А.П. Фро. С. 403.

41 Характерно также соседство фразы Фроси, что она еще «не получала» пояс, и словосочетания «получательжурнала».

42 Какотметил Е.П.Сошкин (см.: https://simon-mag.livejournal.com/230703.html (дата обращения 23.03.202I)), в эпизоде «Фро» содержится реминисценция пушкинской эпиграммы «Словесность русская больна...» (I825 г.), завершающейся «диагнозом»: «Ей Каченовский застудил / Теченье месячныхизданий» (Пушкин А.С. Словесность русская больна... // Пушкин А.С. Полное собрание сочинений. В І7 т. Москва: Воскресенье, 1994. Т. 2. Кн .І. С. 367 ; курсив автора).

43 Неудивительно, если после ожесточённых нападок на повесть «Впрок», в частности после вышедшей в «Красной нови» (1931. № 5-6) разгромной статьи главного редактора (см.: $\Phi a-$ деев A.A. Об одной кулацкой хронике // Андрей Платонов: Воспоминания современников. Материалы к биографии. Москва: Современный писатель, 1994. С. 272-278), этот журнал вызывал у Платонова «кровавые» ассоциации, хотя он и продолжал там печататься. 
писчика» матримониальная тема лишается нормально-эротической составляющей и обретает «бюрократизированный» вид: предлагая героине стать «женщиной» вместо «девушки», он мыслит семью по образцу трудового коллектива - «кровавой» редакции; подразумевается как бы брак без сексуальных отношений и, соответственно, без детей.

«Благовещенский» дискурс можно усмотреть и в «птичьих» мотивах рассказа (хотя речь идёт всё же не о голубе). Губная гармония воспроизводит «скромную мелодию, похожую на песню серой рабочей птички в поле, у которой для песни не остаётся дыхания, потому что сила её тратится в труде» [4: 413]. В финале «Воодушевления» птичка представлена «воочию»- появление Арфы предваряется следующей картиной: «Комната пуста. За окном, во дворе (а не вверху, как прежде) играет детская губная гармоника и умолкает. На подоконник влетает воробей; издав восклицание и пробормотав что-то по-рабочему, он улетает обратно» [7: 523]. После ухода Арфы птица появляется снова: «Второй раз влетает воробей через открытое окно; попрыгав несколько на подоконнике, он перелетает на торт и клюёт его, жадно питаясь» [7: 524]. Затем его место занимает приглашённый Арфой ребёнок - он входит в комнату «прогоняя воробья, прилипшего к торту.

Подвигает табуретку к столу с тортом, забирается на табуретку и начинает есть торт обеими руками» [7: 524] (после чего, как уже говорилось, уносит его с собой). Здесь этот персонаж выступает «антидвойником» воробья, но ни с тем, ни с другим героиня непосредственно не контактирует.

Поскольку мальчик с «воздушной» / «железной» гармонией соединяет героев «андрогинически», травестийно-инцестуозные коннотации заключительной сцены ${ }^{44}$ рассказа свидетельствуют скорее об отсутствии әротического элемента. Характерно сходство деталей в эпизодах бессознательного свидания-расставания героини с Фёдором и её встречи с ребёнком. При «полусонном» общении с мужем «руки еёдержали его руку, он поцеловал её в лоб» [4: 423] - последняя деталь намекает на «бесплотность» отношений. Увидев пришедшего мальчика, «Фрося <...> села передним на пол, взяла руки ребёнка в свои руки и стала любоваться музыкантом» [4: 425], - в глаголе «любоваться», в отличие от «любить», превалирует әстетически-духовная семантика. Что касается повторённого жеста «физического» (посредством рук) контакта ${ }^{45}$, в первом случае он неосознан (Фро дремлет), а во втором выглядит как «детский» - характерно, что сидящая на полу героиня «уравнена» с мальчиком по росту. В психологическом плане «любование» ребёнком можно воспринять как проявление материнского инстинкта, но по сути это сестринское состояние. Фигурально говоря, ребёнок у героини возникает

44 См.: Жолковский А.К. «Фро»: пять прочтений. С. 3 I.

45 Кстати, Фрося отправляется в клуб, в частности, потому, что «ей хотелось <...> подержаться за руки сдругими людьми» [4: 4Iо], то есть испытать ощущение «всеединства» - вновь вспомним про образ «человечества», явившегося ей в виде мальчика. 
«бестелесным» образом ${ }^{46}$, и, думается, неслучайно полные имена главных персонажей - Фёдор и Ефросинья - созвучны именам житийных Петра и Февронии, символизирующих платоническое супружество. Показательна и подпись «другой» Фроси - «Ева»: финал рассказа ассоциируется с состоянием мира до грехопадения, а в перспективе намеченных Фёдором вселенских преобразований - с коммунистическим «искуплением» грехов человечества. В этом контексте обратим также внимание на странное с бытовой точки зрения рассуждение героини о себе: «Может быть, она глупа, может быть, её жизнь стоит две копейки и не нужно её любить и беречь, но зато она одна знает, как две копейки превратить в два рубля» [4: 425]. Подчёркнутое увеличение суммы в сто раз заставляет вспомнить евангельскую притчу о сеятеле, где про одно из зёрен говорится, что оно «упало на добрую землю и, взойдя, принесло плод сторичный» - подразумеваются «те, которые, услышав слово, хранят его в добром и чистом сердце и приносят плод в терпении» ${ }^{47}$. Именно такой «всеобъемлющий» плод обещан героине.

В виде постскриптума зададимся вопросом о возможном «внешнем» источнике звукового комплекса «Фро». Ряд аллюзий был намечен уже давно ${ }^{48}$, но более убедительной кажется версия, высказанная Е.М. Виноградовой, - прежде всего потому, что имеет отношение к рассмотренным пространственным моделям: мотивам ухода и возвращения, «обратного» движения в детство и т. д. «Заглавный» оним рассказа может быть соотнесён с английским фразеологизмом to and fro («туда и обратно», «туда-сюда», «взад-вперёд»). Слово fro - скандинавское заимствование (дублет слова from), причём в английском языке оно закрепилось исключительно в указанном фразеологизме - семантика которого, заметим, близка к платоновской формуле «и так, и обратно» [3: 92, 234, 340], воплощающей идею равноправного сосуществования «противоположных» моделей мира ${ }^{49}$.

Может показаться странным, что речь об английских аллюзиях заходит в связи с «простонародными» жителями российской глубинки. Однако, по-видимому, не случайно среди терминов, которые безуспешно пыталась постигнуть Фрося, акцентирована микрофарада - название единицы электрической ёмкости образовано от фамилии английского ученого М. Фарадея, которая созвучна именам платоновских персонажей. К тому же «среди танца» героиня,

46 Поскольку выше заходила речь о диалоге Платона «Тимей», можно отметить, что в нём, как и в книге «Государство» (см.: Платон. Государство. С. 232), высказана идея «общности» детей - «чтобы никто и никогда не мог знать, какой младенец родился именно от него, но каждый почитал бы каждого родным себе» (Платон. Тимей. С. 422).

47 Лк. 8:15.

48 См.: Жолковский А.К. «Фро»: пять прочтений. С. 39.

49 См.: Яблоков Е.A. Принцип художественного мышления А. Платонова «и так, и обратно» в романе «Чевенгур» // Филологические записки. 1999. № 13. С. 14-27; Яблоков Е.А. На берегу неба: Роман Андрея Платонова «Чевенгур». Санкт-Петербург: Дмитрий Буланин, 200I. C. 70, 220-22I. 
именуя себя «Фро», настаивает, что она «иностранка», - хотя собеседнику прекрасно известно, что перед ним дочь «русского Евстафьева» [4: 4II-4I2]. При всей бурлескности сцены в ней содержится намёк на сущностную «раздвоенность» героини, реализованную через оппозицию онимов ${ }^{50}$. Заметим также, что английская тема сама по себе имеет существенное значение в платоновском творчестве - показательны повесть «Епифанские шлюзы» (1926 г.) и рассказ «Война» (1927 г.).

Правдоподобность версии подтверждается и наличием «английского» онима в более позднем рассказе «Афродита» (1943 г.), образ главной героини которого тоже построен на мотиве переименования Наталья / Aфродита [5: 342], причём один из онимов воспроизводит имя случайной подруги Фроси, а в другом как бы соединены имена «Фро» и «Арфа». Но в данном случае обратим внимание не на главную, а на второстепенную героиню. В одном из әпизодов «Афродиты» девушка по имени Евдокия Ремейко, отдавшая на строительство әлектростанции все свои сбережения, после пожара предлагает «снова собрать средства и снова отстроить погоревшую станцию» [5: 353] - этому абсолютно соответствует её фамилия, представляющая собой славянизированное англ. remake - «переделать, сделать заново». Заметим также, что, как и оним «Фро», фамилия «Ремейко» напоминает существительное среднего рода.

При всём «жизнеподобии» сюжета в рассказе «Фро»кажется бессмысленным фантазировать о том, как сложится жизнь персонажей «дальше»: возвратится ли Фёдор из бесконечно-дальних странствий; родится ли (и от кого) у Фроси собственный ребёнок; чем станет она зарабатывать на жизнь; будет ли мальчик с верхнего этажа дальше навещать героиню и т. д. Фро - не только «общий» оним Фроси и Фёдора, но как бы имя ребёнка-носителя гармонии, символизирующего идеальное единство противоположностей человечества и человека. Это образ будущей «встречи», к которой герои рассказа (и люди вообще) придут разными путями. «Объединяющий» оним предстаёт символом компромисса, или, точнее, синтеза двух способов достижения «вселенски-детского» мироощущения - статичного слияния с бытиём и бесконечного преобразующего странствия, сутью которого является возвращение в детство.

50 В сочетающем «обыденность» и «нездешность» образе Фроси / Фро предварена формула «Ассоль из Моршанска» [8: 178], употреблённая Платоновым в статье «Рассказы А.С. Грина» (1938 г.) о повести «Алые паруса». Характерно, что автор этой повести с дореволюционных времён воспринимался именно как «англичанин»- например, Ц.С. Вольпе в 1935 г. писал: «Рассказы Грина кажутся и сейчас искусной имитацией английской авантюрной новеллы» (Вольпе Ц. Об авантюрно-психологических новеллах А.С. Грина // Грин А. Рассказы. Ленинград: Издательство писателей в Ленинграде, 1935. С. 7). 


\section{Bibliografia}

Borisov S., 2019, «Davajte flirtovat', tovarishchi!», „Rodina”, № 5, s. I26-I29.

Boecij A.M.S., 2oı2, Osnovy muzyki, Moskovskaya konservatoriya, Moskva.

Fadeev A.A., 1994, Ob odnoj kulackoj bronike, [w:] Andrej Platonov: Vospominaniya sovremennikov. Materialy k biografii, Sovremennyj pisatel', Moskva, s. 272-278.

Gasparov M.L., 1980, Primechaniya [w:] Pindar. Vakkhilid. Ody. Fragmenty. Nauka, Moskva, s. $387-496$.

Gomer, 1935, Odisseya, przeł. V.A. Zhukovskiy, Academia, Moskva, Leningrad.

Gurvich A.S., 1994, Andrej Platonov, [w:] Andrej Platonov: Vospominaniya sovremennikov. Materialy k biografii Sovremennyj pisatel', Moskva: s. 358-4I2.

Kurlyandskij I.A., 2oII, Stalin, vlast', religiya (religioznyj i cerkovnyj faktory vo vnutrennej politike sovetskogo gosudarstva), Kuchkovo pole, Moskva.

Nicshe F., 1990, Tak govoril Zaratustra, [w:] Nicshe F., Sochineniya, t. 2, Mysl', Moskva, s. 5-237.

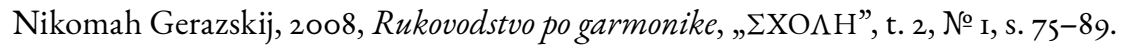

Ostrovskij N., 1969, Kak zakalyalas'stal', [w:] Ostrovskij N., Sochineniy, t. I, Pravda, Moskva, s. 23-394.

Pindar, 1980, Olimpijskie pesni, [w:] Pindar. Vakkhilid, Ody. Fragmenty, wyd. M. Gasparov, F. Petrovskij, Nauka, Moskva, s. 8-57.

Platon 1993, Pir, [w:] Platon, Sobraniye sochineniy, t. 2, Mysl', Moskva, s. 8I-I34.

Platon, 1994, Gosudarstvo, [w:] Platon, Sobraniye sochinenij, v 4 t., t. 3, Moskva: Mysl', s. 79-420.

Platon, 1994b, Timej // Platon. Sobraniye sochineniy, t. 3, Mysl', Moskva, s. 42I-500.

Platonov A.P., 1971, Fro, [w:] Platonov A.P., Techeniye vremeni, Moskovskij rabochij, Moskva, s. 389-408.

Platonov A.P., 20II-20I2, Sobraniye, 8 tomów, Vremya, Moskva.

Pervye posmertnye sborniki A. Platonova: otzyvy sovremennikov, 20I7, [w:] «Strana filosofov» Andreya Platonova: problemy tvorchestva, vyp. 8, IMLI RAN, Moskva, s. 560-622.

Pushkin A.S., 1994, Slovesnost' russkaya bol'na... [w:] Pushkin A.S. Polnoe sobranie sochinenij, t. 2, kn. I, Voskresen'e, Moskva, s. 367.

Solov'ev V.S., 19I4, Stat' i iz Enciklopedicheskogo slovarya, [w:] Solov'ev V.S., Sobranie sochinenij, t. Io, Prosveshchenie, Sankt-Peterburg, s. 229-523.

Vol'pe C., 1935, Ob avantyurno-psibologicheskih novellah A.S. Grina, [w:] Grin A. Rasskazy, Izdatel'stvo pisatelej v Leningrade, Leningrad, s. 5-22. 
Yablokov E.A., 1999, Princip hudozhestvennogo myshleniya A. Platonova "i tak, i obratno" v romane «Chevengur», „Filologicheskie zapiski”, № 13, s. I4-27.

Yablokov E.A., 20oI, Na beregu neba: roman Andreya Platonova «Chevengur», Dmitrij Bulanin, Sankt-Peterburg.

Yablokov E.A., 2009, Platonov i literatura, „Wiener Slawistischer Almanach”, t. 63, s. 25I-264.

Yablokov E.A., 2017, Izmenit' mir do uznavaemosti: revolyucionnyj passeizm Andreya Platonova, [w:] «Skrytaya teplota revolyucyi»: poetika Andreya Platonova, t. 3, Polimedia, Moskva, s. $157-178$.

Zholkovskij A.K., 1989, «Fro»: pyat'prochtenij, „Voprosy literatury”, № I2, s. 23-49.

\section{STRESZCZENIE}

Światowa triada dźwiękowa. Opowieść Andrieja Ptatonowa Fro. Symbolika fabuty i znaczenie tytutu

Artykuł został poświęcony jednemu z najbardziej znanych dzieł Płatonowa. Fabuła „Fro” jest często interpretowana jako opowieść czysto „rodzinna”, jednakże analiza wykazuje, że treść tej opowieści wykracza znacznie poza ramy codziennej psychologii. Tekst Płatonowa zawiera wiele szczegółów, które nadają przedstawionym wydarzeniom znaczenia symbolicznego i ponadczasowego. Jest to wyraźnie widoczna w nazewniczym systemie opowieści. Umieszczone w tytule egzotyczne deminutivum Fro (od imienia - Efrosina) jest postrzeganego $\mathrm{z}$ „codziennego” punktu widzenia jako atrybut konkretnej bohaterki. Jednakże w artystycznej całości wypełnia on symboliczną funkcję imienia „uniwersalnego”. Imię „Fro” oznacza bowiem idealny „cel” ludzkości, uosabia ono obraz powszechnej jedności, symbolizuje nie tylko przyszłe „spotkanie” bohaterów tej konkretnej opowieści, ale także wspólnotę ludzi w całym przemienionym świecie.

\section{SŁOWA KLUCZOWE}

A. Płatonow, poetyka, model świata, nazewnictwo, symbolika codziennych sytuacji,

\section{ABSTRACT}

The World Sound Triad. Andrei Platonov's Story Fro: The Symbolism of the Plot and the Meaning of the Title

The article is devoted to one of the most famous Platonov's story Fro. The plot is often interpreted as a "family" story, but the analysis shows that the content of the story is far beyond the framework of everyday psychology. The text contains many details that give the symbolic, timeless meanings to the depicted events. This feature is clearly manifested in 
the onomastics system of the story. The exotic onym "Fro" put in the title is the diminutive name of Efrosinya, perceived as an attribute of the heroine from the "profane" point of view. But within the framework of the artistic whole, onym "Fro" has the symbolic function as a "panhuman" name. "Fro" denotes the ideal "goal" of humanity, embodies the image of all-unity, symbolizes not only the future "meeting" of the heroes of the story, but also the community of people in the transformed world.

KEY WORDS

Andrei Platonov, poetics, model of the world, onomastics, symbolism of everyday situations 